\title{
ECOLOGICAL AND COMPARATIVE ANALYSIS OF THE INFLUENCE OF WEATHER AND CLIMATE CONDITIONS ON THE VEGETATIVE BALANCE OF YOUNG BOYS AND ADOLESCENTS OF DIFFERENT AGE GROUPS
}

\author{
O. Furdychko ${ }^{1}$, O. Mudrak ${ }^{2}$, O. Yermishev ${ }^{3}$, H. Mudrak ${ }^{4}$ \\ ${ }^{1}$ Інститут агроекології і природокористування НААН (м. Київ, Україна) \\ e-mail: agroecologynaan@gmail.com; ORCID: 0000-0002-1108-7733 \\ ${ }^{2}$ КЗВО «Вінницька академія безперервної освіти» (м. Вінниия, Україна) \\ e-mail: ov_mudrak@ukr.net; ORCID:0000-0002-1776-6120 \\ 3 Донецький національний університет імені Василя Стуса (м. Вінниия, Україна) \\ e-mail: o.yermishev@donnu.edu.ua; ORCID:0000-0001-5854-9678 \\ ${ }^{4}$ Вінницький національний аграрний університет (м. Вінниия, Україна) \\ e-mail: galina170971@ukr.net; ORCID:0000-0003-1319-9189
}

Наразі, коли техногенні і соціальні умови активно посилюють негативну дію екологічних факторів, особливості кліматичних впливів стають одним з визначальних чинників самопочуття людини. В епоху урбанізації та індустріалізації люди більшу частину життя проводять у приміщенні в комфортних або субкомфортних умовах мікроклімату, що знижує його пристосувальні реакції до мінливих погодних параметрів. У результаті порушується динамічна рівновага між організмом людини $i$ зовнішнім середовищем та стан функціональної активності органів і систем організму. Встановлено, що реакція організму на різні стресові впливи значною мірою визначається співвідношенням тонусу симпатичного і парасимпатичного відділів вегетативної нервової системи. Саме вегетативній нервовій системі (ВНС) i, передусім, їі симпатичному відділу належить особлива роль у формуванні пристосувальних реакцій організму, розвитку метеотропних реакцій, тобто вегетативна нервова система є первинним місием докладання метеорологічних впливів, що викликають зрушення в їі рівновазі. Визначення вегетативного статусу та спрямованість вегетативної активності в організмі хлопиів проводили за допомогою функціонально-вегетативної діагностики за методом В. Макаца. Було обстежено 1206 хлопиів, з яких 215 хлопиі віком 711 років, 861 - віком 12-15 років та 130 хлопців віком 16-21 років, ФВД проводилася ранком в $10^{00}-11^{00}$. Оскільки стан вегетативної нервової системи $\epsilon$ визначальним у розвитку метеотропних реакцій проведено аналіз даних дослідження вегетативного тонусу у сонячну, мінливу, хмарну та дощову погоду й визначення сприятливих і несприятливих погодних умов для організму. Було виявлено, що за впливу метеорологічних факторів на організм практично здорових молодих хлопиів спостерігаються вікові особливості проявів метеолабільності. Найбільш чутливою до змін погодно-кліматичних умов виявилась група хлопиів 16-21 років, в яких спостерігались максимальні відхилення показників активності функціональних систем від вікової норми, а найменш чутливою виявилась група хлопців 12-15 років. При аналізі впливу змін погодних станів на організм хлопиів за вегетативним коефіцієнтом ( $k V)$ було виявлено, що при нормі показника $k V$ 0,87-1,13, він максимально збільшувався за дії на організм дощової погоди і становив 1,23, шо свідчить про виражену симпатикотонію, за дії на організм мінливої та хмарної погоди симпатикотонія набуває менш виражених значень, 1,08 та 1,13, відповідно. Найбільш еколого-фізіологічним фактором впливу на організм можна вважати сонячну погоду. $B$ здоровому організмі зміни фізіологічних процесів і функціональної активності систем під впливом такого фактора, як зміна погоди, легко компенсуються і особлива роль у иьому належить вегетативній нервовій системі, діяльність якої забезпечує адекватну реакцію організму на вплив факторів зовнішнього середовища.

Ключові слова: погода, адаптація, функціональні системи, вегетативна нервова система.

(C) O. Furdychko, O. Mudrak, O. Yermishev, H. Mudrak, 2020 


\section{INTRODUCTION}

Nowadays, whileman-made and social conditions are actively exacerbating the negative effects of environmental factors, the peculiarities of climatic influences are becoming one of the determining factors of human well-being [1-3]. Taking into account that in the era of urbanization and industrialization people spend most of their lives indoors and the longer the body is isolated from external climatic factors and is in comfortable or subcomfortable conditions of the room microclimate, the less its adaptive responses to ever-changing weather parameters are. As a result, the dynamic balance among the human body and the external environment as well as the state of functional activity of organs and systems of the body is disturbed [4]. According to medical statistics, about $75 \%$ of people «feel the weather». In addition, today the effect of weather on the so-called weatherdependent people, which manifests itself in deteriorating health, exacerbation of chronic diseases and even increasing mortality $[5 ; 6]$ is well-known. Therefore, sharp changes in atmospheric pressure can provoke deterioration of state of health of people with unstable arterial pressure, vegetative-vascular dystonia and hypertension. This is due to changes in the functional state of the organism caused by adaptive loads proportional to the difference (contrast) between the new values of the parameters and their «usual values» $[7 ; 8]$.

\section{ANALYSIS OF RECENT RESEARCH}

The response of an organ, tissue or physiological system to the action of a stimulus is known to depend significantly on their initial state. It has been established that the body's response to various stressors is largely determined by the ratio of the tone of the sympathetic and parasympathetic divisions of the autonomic nervous system $[9 ; 10]$. It is the autonomic nervous system (ANS) and, above all, its sympathetic department thattakes a special part in the formation of adaptive reactions of the body, the development of meteorological reactions, i.e the autonomic nervous system is the primary site of meteorological influences that cause changes in its balance. Influencing the corresponding baro, thermo-, chemo and other receptors, meteorological factors cause activation of the sympathetic nervous system, its desynchronization, i.e internal inconsistency of independent rhythms, which is expressed by the suppression of immune function, changes in thermoregulation, the emergence of vegetative-visceral adverse weather [5; 11; 12]. The activity of the autonomic nervous system is aimed at ensuring the necessary functional state of physiological systems for an adequate response of the body to environmental influences. Since the functional background of the ANS in humans is different, the reactions to meteorological changes are the subjects to significant fluctuations.

The works of many authors have shown that during the changes in meteorological conditions, the features of functional adjustment depend not only on gender, duration of residence in a particular environment, biorhythmological features, but also on the age of the individual $[11 ; 13]$. Physicians note that at the time of changing meteorological conditions more attention should be paid to the health of children, as the child's body is not yet able to effectively maintain homeostasis, providing physiological adaptation to changing environmental conditions $[6 ; 11]$.

The aim of the study. To conduct an ecological-comparative analysis of the influence of meteorological factors on the tone of the autonomic nervous system and the functional state of the body of boys and young men and to assess in terms of their impact on the human body.

\section{MATERIALS AND METHODS OF RESEARCH}

Changes in the physiological state of the body are manifested by the transformation of electro-skin resistance in certain functionalactive zones (FAZ) of the skin, which are topographically coinciding with the course of 12 classical acupuncture meridians (functional systems) - lungs (LU), pericardium (PC), heart (HT), small intestine (SI), condition of the lymphatic system (TE), large intestine (LI), spleen and pancreas (SP), liver (LR), 
kidney (KI), bladder (BL), gall bladder (GB) and stomach (ST). For diagnostics, correlations between the conductivity changes in 24 representative FAZs (characterizing the state of the meridian in general) and the state of classical acupuncture meridians determining. Using V. Makats method (functionalvegetative diagnostics (FVD), we examined 1206 boys, 215 boys aged $7-11,861$ - aged $12-15$ and 130 boys aged $16-21$, who underwent sanatorium and health improvement in sanatoriums of Ukraine. FVD was conducted twice in the morning (10.00-11.00). The bioelectric activity of 12 symmetric pairs of functionally active zones of the skin (24 FAZ), 12 on the hands and 12 on the feet were studied, reflecting the functional activity of the sympathetic and parasympathetic nervous system [12]. FVD according to the method of V. Makats and devices for its implementation are approved officially by the Ministry of Health of Ukraine «New Medical Equipment and New Methods of Diagnosis» (№ 5 from 25.12.91; № 1.08-01 from 11.01.94) and the Scientific Council of the Ministry of Health of Ukraine (No. 1.08-01 of 11/01/94). For FVD a VITA $01 \mathrm{M}$ device is used, the voltage in the closed circuit of which does not exceed the levels of membrane potentials $(1-5 \mu \mathrm{A} ; 0.03-0.6 \mathrm{~V})$ and which does not need external energy sources for its work. It has 2 diagnostic electrodes, a base electrode acceptor of electrons (AE) - a convex plate of a special alloy, pre-coated with an oxide film $(5-7 \mathrm{~cm})$ and 2 paired diagnostic electrodes (D-electron donors) in the form of a silver pair, which are located in ebonite cups with a diameter of $1 \mathrm{~cm}$ and wrapped with foam gaskets. The base electrode (BE) is fixed by a special belt through a wet pad (moistened with saline) in the umbilical region (central mesogastric area (0-zone) with medium density tension to create stable inspection conditions. Diagnostic electrodes (DE) are also moistened with saline. In the process of testing DE electrodes at right angles with low pressure (at the level of touch), simultaneously contact with each pair of symmetric FAZ (left-right at each extremity) within 1-4 seconds before obtaining stable indicators in microamperes. After every 3 contacts the FAZs electrodes are re-moistened with saline solution. The obtained in $\mathrm{mA}$ data FVD are converted into relative values, the obtained data are compared with the norm and it is concluded the degree of deviation from it and the level of impaired functional health [12]. Mathematical and statistical processing of the results of observations was carried out using the method of nonparametric statistics proposed by Derevyanko, 1990 to determine the magnitude of the shift of the function under study [14].

\section{RESULTS AND DISCUSSION}

People have become more sensitive to environmental influences due to reduced immunity and excessive urbanization. On the other hand, the weather has become less predictable, with frequent, sharp and extreme fluctuations associated with both global warming and strong anthropogenic impacts on the planet's climate. Until recently, meteorological dependence, and especially meteopathy, was thought to be present only in adults and children were relatively insensitive to weather changes. But recent studies show that reactions to weather changes are inherent in children [1;2]. More than half of children under the age of 5 perceive changes in the weather and respond to deteriorating health, fuss and psychosomatic disorders. Newborns react sharply to changes in atmospheric pressure, because their fonticulus are not closed yet as well as all systems and organs are still immature. Preschoolers and younger students experience a difficult period of development, so due to psychophysiological and physical overload respond to weather changes inadequately [8; 15]. Thus, the child's body can react significantly to changes of weather, but in the absence of chronic diseases and pathologies, these reactions are compensated. It should be borne in mind that weather changes can have not only negative but also positive effects.

In a study of systemic age dependence in the male group of primary school age (PSA) of 7-11 years old under different weather conditions, it was found that changes in 
weather conditions lead to changes in functional activity and homeostasis of the body (Fig. 1). It is clear that the activity indicators of functional systems (FS) in different weather conditions duplicate the line of the norm, differing in amplitude, i.e have the same direction. Moreover, in the presence of significant changes in the studied parameters of the activity of the FS with the norm line, it is not possible to detect the main dysregulatory weather condition. The smallest changes in the activity of functional systems are observed in sunny weather, which is manifested by a strong increase in the activity of FS spleen and pancreas (SP), which is a pacemaker of the sympathetic nervous system [16].

In variable weather, there are maximum deviations of FS activity in relation to the functional-age norm in FS of the heart (HT) and small intestine (SI) and a decrease in FS of the liver (LR), kidney (KI) and stomach (ST). In cloudy weather, there is an increase in FS activity relative to the functional-age norm in bladder FS (BL), which acts as a pacemaker of the parasympathetic nervous system [16] and a decrease in the activity in PS pericardium (PS) and colon (LI). In general, parasympathicotonia is an unfavorable factor for the process of adaptation of the organism, as it leads to depletion of functional reserves and reduced lability of the autonomic reactions. In general, a rather chaotic pattern

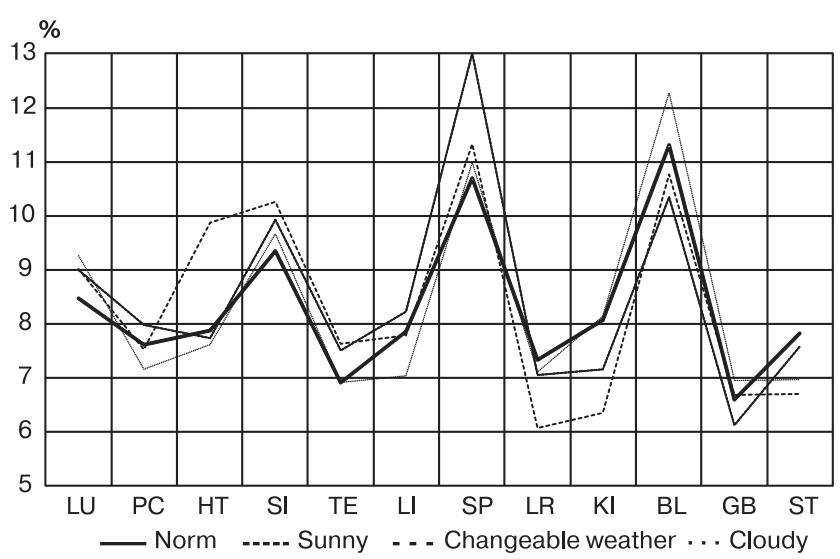

Fig. 1. Systemic age dependence in the male group of primary school age (PSA) 7-11 years old under different weather conditions, $\mathrm{p} \leq 0.05$ of functional dependencies can be associated with physiological and functional immaturity of adaptation processes and the speed of their formation and stabilization in children aged $7-11$ years old [2; 13; 17]. The rapid pace of morphological and functional development of all organs and systems, the immaturity of the immune system during this period contribute to the sensitivity of children to ecological, physiological and pathologicalchanges in environmental factors.

Puberty is a transitional stage from the child development to adult stage of ontogenesis. The transition process of puberty captures absolutely all levels of biological organization of the teenager from changes in the structure of the skeleton, respiratory system, blood circulation to the reproductive system, its functional and structural support. There are an activation of the pituitary gland, intensive physical and physiological development, restructuring of the motor apparatus and neurohumoral relationships. During puberty, children experience sharp fluctuations in hormonal status as well as active growth of the body. Therefore, their weather sensitivity can be pronounced. In the study of systemic age dependence in the male group of juvenile school age (JSV) 12-15 years old under different weather conditions, it was found that their change leads to corresponding changes in functional activity and homeostasis of the organism (Fig. 2).

There are changes in the activity of FS, with a much smaller amplitude, but the nature and direction of changes in activity are similar, compared with the preschool group. The analysis of the figure shows the stabilization of adaptive mechanisms in the body of boys in this group of observations.

Adolescent school age has its own characteristics of ecological and physiological development. Individual development combines periods of evolutionary (gradual) morpho-functional maturation and periods of «revolutionary», turning points of the development, which are associated with both internal 
(biological) factors of development and external (social) factors. In contrast to the sensitive periods, characterized by increased sensitivity of individual functions, these periods are characterized by significant qualitative transformations that occur simultaneously in different physiological systems and brain structures that determine the formation of mental processes. In adolescence, the inconsistency in the hormonal regulation of metabolism and physiological functions is eliminated. Morphofunctional rearrangements of the basic physiological systems at these stages of the development cause stress of homeostatic mechanisms, an increase in energy consumption, high sensitivity to a set of environmental factors, which allows to classify this period to be critical. The mismatch of environmental influences to the features and functional capabilities of the organism at these stages of thedevelopment can have particularly detrimental consequences for the organism.In the study of systemic age dependence in the male group of adolescent school age (ASA) 16-21 years old under different weather conditions, it was found that changes in weather conditions lead to significant changes in functional activity and homeostasis of the body (Fig. 3). Indicators of activity of functional systems (FS) in different weather conditions are unidirectional with the line of the age norm and differ in amplitude.

Due to the nature of the picture we can note the uncharacteristic reaction of the body to various weather factors. But the peak activity of FS is more often detected by the effects of cloudy weather on the body and the slightest changes in the activity of functional systems are observed in sunny weather.

The activation of functional activity of the spleen and pancreas (SP) is the peculiarity of

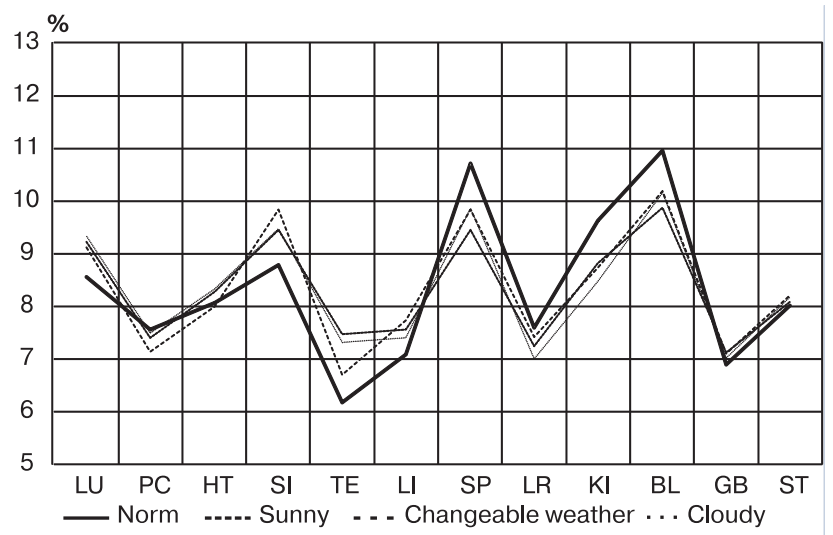

Fig. 2. Systemic age dependence in the male group of juvenile school age (JSV) 12-15 years old under different weather conditions, $\mathrm{p} \leq 0.05$

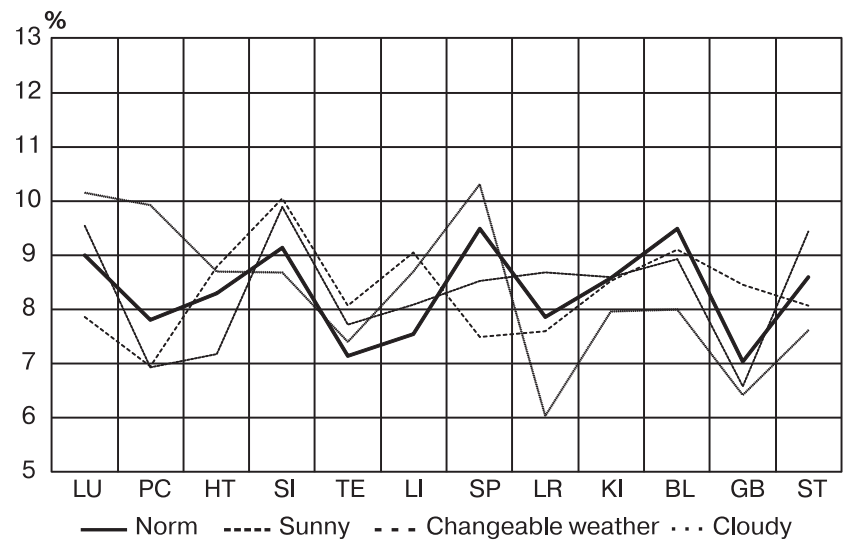

Fig. 3. Systemic age dependence in the male group of adolescent school age (ASA) 16-21 years old under different weather conditions, $\mathrm{p} \leq 0.05$

the influence of cloudy weather on the body of this age group, which is a pacemaker of the sympathetic nervous system and a sharp suppression of functional activity of the bladder (BL), which acts as a pacemaker of the parasympathetic nervous system. This may indicate an overstrain of the body's adaptive mechanisms.

Thus, the influence of meteorological factors is more pronounced in young children and during puberty, which is likely in the first case due to the lack of functional systems of the body, and in the second one - with their 


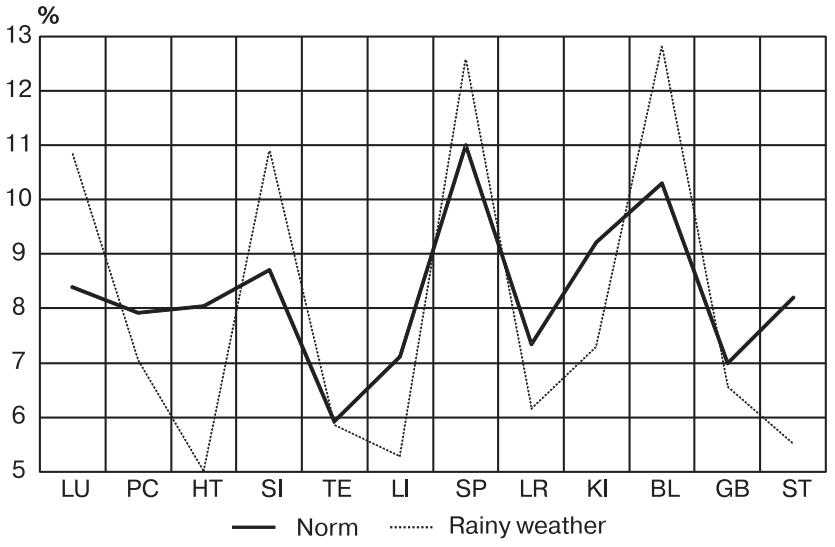

Fig. 4. Systemic age dependence in the mixed age male group under rainy weather, $\mathrm{p} \leq 0.05$

restructuring associated with sexual maturation and its completion.

In the study of system-age dependence in the mixed age male group under the influence of rainy weather on the body revealed pronounced amplitude fluctuations in the activity of functional systems to the zone of functional-age norm, indicating high stress of rainy weather on the body and reduced adaptive reserves (Fig. 4).

While analyzing the impact of changes in weather conditions on the body of boys by vegetative coefficient $(\mathrm{kV})$ it was found that at a rate of $\mathrm{kV} \quad 0.87-1.13$ it increased as much as it was possible on the effects of rainy weather and got up to 1.23 , which indicates a pronounced sympathicotonia. In addition, under the influence of cloudy and variable weather on the body sympathicotonia acquires less pronounced values.

The most ecological and physiological factor influencing the body can be considered sunny weather. Among age groups, the group of young school age 16-21 years is the most sensitive to changes in weather conditions (Table).

Thus, the meteorological sensitivity is a reaction of an organism to changes of weather conditions and it unites all types of reactions of an organism to action of weather factors. It should be noted that the occurrence of a meteotropic reaction may appear before visible changes in weather conditions and then it is a signal reaction. Or, conversely, it is a sequential reaction if a meteotropic reaction possibly occurs soon after a change of weather [13; 18].

There are three phases in the development of meteotropic reactions: the phase of clinical and physiological adaptation of the organism to the influence of atmospheric and physical factors is the first one; the second phase is the phase of hypersensitivity to these factors manifested by changes in neuropsychological, immune-allergic reactivity; the third one is the phase of maladaptation to the weather which manifests itself in healthy people with various functional syndromes and in patients with the appearance of clinical and subclinical reactions and exacerbations of diseases, i.e meteotropic reactions lead to structural and functional changes in the human body, disorders of compensatory reactions which are manifested by various symptom complexes $[19 ; 20]$. The mobilization of mechanisms aimed at mitigating and stabilizing the processes leading to the strengthening of

Vegetative coefficient $\mathrm{kV}$ under the influence of different weather conditions

\begin{tabular}{l|c|c|c|c}
\hline \multicolumn{1}{c|}{ Weather condition } & PSA & JSA & ASA & Average value \\
\hline \hline Sunny & 1.03 & 0.95 & 0.99 & 0.99 \\
\hline Changing weather & 1.06 & 1.01 & 1.16 & 1.08 \\
\hline Cloudy & 1.2 & 0.99 & 1.19 & 1.13 \\
\hline \multicolumn{5}{|c}{ Mixed age grop } \\
\hline Rainy weather & 1.23 & 1.23 \\
\hline
\end{tabular}


adaptive mechanisms is in cells, tissues and the body as a whole. It is known that the body's reaction to the weather is determined by sex, age, height, body weight, physique, temperament, and the nature of nutrition. At long and repeated actions of weather and meteorological factors there is a reaction of internal secretions which is considered to be a «stress reaction» of the general adaptation syndrome. Under their influence, enzymatic processes change, the intensity of glycolysis, the level of basal metabolism, the structure of colloids of blood and tissues are disturbed [8]. When determining the degree of climate impact on humans, it should be borne in mind that the body's response to its impact depends on the success of adaptation to weather and climatic conditions.

\section{CONCLUSIONS}

Thus, the study of the influence of meteorological factors on the body of almost healthy boys of different ages gives grounds to talk about the age characteristics of the manifestations of meteorological lability. It was found that the change of autonomic balance in the direction of increasing sympathetic activity in the body of boys occurs under the action of rainy and cloudy weather. It was also confirmed that in a healthy body changes in physiological processes and functional activity of systems under the influence of such factors as weather changes are easily compensated. In these compensatory mechanisms a special role belongs to the autonomic nervous system, the activity of which provides an adequate response of the organism to the influence of environmental factors. The knowledge of meteorological sensitivity and meteopathic reactions is necessary for the development of both preventive and curative measures aimed at increasing non-specific resistance and adaptation mechanisms of the body, the normalization of organ and system function as a basis for normal reactions to adverse environmental changes.

\section{ЛITЕРАТУРА}

1. Гордиевский А.Ю., Гордиевская Н.А. Влияние метеоусловий как экологического фактора вегето-соматические показатели организма дошкольников. Самарский научный вестник. 2016. № 1 (14). C. 23-26.

2. Григорьев А.И., Григорьев К.И. Роль неблагоприятных факторов окружающей среды в формировании нарушений адаптации у детей и подростков. Медицинская сестра. 2018. № 7. C. 32-38. DOI: https://doi.org/10.29296/258799792018-07-07.

3. Chmura H.E., Glass T.W., Williams C.T. Biologging Physiological and Ecological Responses to Climatic Variation: New Tools for the Climate Change Era. Ecology and Evolution. 2018. Vol. 6. Article 92. DOI: https://doi.org/10.3389/fevo.2018.00092.

4. Furdychko O.I., Mudrak O.V., Yermishev O.V., Mudrak H.V. Vegetative status of children as a territorial bio-indicator of ecological safety. Ukrainian Journal of Ecology. 2020. 10 (3). P. 191-196 .DOI: https:// doi.org/10.15421/2020_153.

5. Rahman S. et al. Stay in or play out? The influence of weather conditions on physical activity of grade 5 children in Canada. Canadian journal of public health. 2019. Vol. 110, № 2. P. 169-177. DOI: https://doi.org/10.17269/s41997-019-00176-6.

6. Udovenko I.L., Hechumyan A.F., Sidorenko N.Yu., Nadeina O.S. Evaluation of Natural and Climatic Resources in Order to Develop Preservation of Health Technology and Human Adaptation to Anthropogenically. European Journal of Medicine. Series
B. 2015. Vol. 2. № 1. P. 60-76. DOI: https://doi. org/10.13187/ejm.s.b.2015.2.60.

7. Григорьев К.И., Поважная Е.Л. Проблема повышенной метеочувствительности у детей и подростков. Российский вестник перинатологии и педиатрии. 2018. Т. 63, № 3. С. 84-90.

8. Куценко Т.В. Вплив метеорологічних факторів на показники організму дітей різного віку. Вісник Черкаського університету. 2015. № 2. С. 67-71.

9. Jänig W. Integrative Action of the Autonomic Nervous System. Neurobiology of Homeostasis. Cambridge: Cambridge University Press, 2008. $636 \mathrm{p}$.

10. Parashar R., Amir M., Pakhare A., Rathi P. Age Related Changes in Autonomic Functions. Journal of Clinical and Diagnostic Research. 2016. Vol. 10. № 3. P. 11-13. DOI: https://doi.org/ 10.7860/JCDR/2016/16889.7497.

11. Новиков В.С., Сороко С.И. Физиологические основы жизнедеятельности человека в экстремальных условиях. Сант-Петербург: Политехника-принт, 2017. 476 с.

12. Ходаков В.Е., Соколова Н.А., Чёрный С.Г. Влияние природно-климатических факторов на социально-экономические и производственные системы: моногр. Херсон, 2013. 354 с.

13. Gosling S.N. et al. Adaptation to Climate Change: A Comparative Analysis of Modeling Methods for Heat-Related Mortality. Environmental Health Perspectives. 2017. DOI: https://doi.org/10.1289/ EHP634. 
14. Деревянко Е.А., Лихачева О.А., Степанова Л.П. Интегральная оценка работоспособности при умственном и физическом труде. Москва: Экономика, 1990. 109 с.

15. Yabluchanskiy M.I. et al. From physiological to pathological meteosensitivity. Journal of V.N. Karazin' KhNU. 2013. № 1090. P. 5-8.

16. Макац В.Г., Курик М.В., Петрук В.Г., Срмішев О.В. Основи функціонально-екологічної експертизи (невідома вегетологія). Том VI: моногр. Вінниця: Наукова ініціатива, 2018. 128 с.

17. Peng Y.-F. et al. Analyzing Personal Happiness from Global Survey and Weather Data: A Geospatial Approach. Plos one. Vol. 11. № 4. 2016. P. 1-17. DOI: https://doi.org/10.1371/journal.pone.0153638.
18. Henderson K., Loreau M. How ecological feedbacks between human population and land cover influence sustainability. PLoS Comput Biol. 2018. 14(8).

19. Єрмішев О.В., Мудрак О.В. Еколого-порівняльний аналіз функціонального здоров'я чоловіків різних вікових груп радіаційно забруднених та умовно чистих регіонів України. Біоресурси і природокористування. 2019. Т. 11. № 5-6. С. 112128. DOI: http://dx.doi.org/10.31548/bio2019. 05.012 .

20. Parry M.L. et al. Climate Change: Impacts, Adaptation and Vulnerability, Contribution of Working Group II to the Fourth Assessment Report of the IPCC. Cambridge: Cambridge University Press, 2007. 163 p.

\section{REFERENCES}

1. Gordievskiy, A.Yu. \& Gordievskaya, N.A. (2016). Vliyaniye meteousloviy kak ekologicheskogo faktora vegeto-somaticheskiye pokazateli organizma doshkol'nikov [Influence of meteorological conditions as an ecological factor vegetative-somatic indicators of the organism of preschoolers]. Samarskiy nauchnyy vestnik - Samara Scientific Bulletin, 1(14), 23-26 [in Russian].

2. Grigorev, A.I. \& Grigorev, K.I. (2018). Rol' neblagopriyatnykh faktorov okruzhayushchey sredy v formirovanii narusheniy adaptatsii u detey i podrostkov [The role of unfavorable environmental factors in the formation of adaptation disorders in children and adolescents]. Meditsinskaya sestra - Nurse, 7, 32-38. DOI: https://doi.org/10.29296/258799792018-07-07 [in Russian].

3. Chmura, H.E., Glass, T.W. \& Williams, C.T. (2018). Biologging Physiological and Ecological Responses to Climatic Variation: New Tools for the Climate Change Era. Ecology and Evolution, 6, Article 92. DOI: https://doi.org/10.3389/fevo.2018.00092 [in English].

4. Furdychko, O.I., Mudrak, O.V., Yermishev, O.V. \& Mudrak H.V. (2020). Vegetative status of children as a territorial bio-indicator of ecological safety. Ukrainian Journal of Ecology, 10(3), 191-196. DOI: https://doi.org/10.15421/2020_153 [in English]

5. Rahman, S. et al. (2019). Stay in or play out? The influence of weather conditions on physical activity of grade 5 children in Canada. Canadian journal of public health - Revue canadienne de sante publique, 110(2), 169-177. DOI: https://doi.org/10.17269/ s41997-019-00176-6 [in English].

6. Udovenko, I.L., Hechumyan, A.F., Sidorenko, N.Yu. \& Nadeina, O.S. (2015). Evaluation of Natural and Climatic Resources in Order to Develop Preservation of Health Technology and Human Adaptation to Anthropogenically. European Journal of Medicine. Series B, 2(1), 60-76. DOI: https://doi. org/10.13187/ejm.s.b.2015.2.60 [in English].

7. Grigoryev, K.I. \& Povazhnaya, E.L. (2018). Problema povyshennoy meteochuvstvitel'nosti u detey i podrostkov [The problem of increased meteosensitivity in children and adolescents]. Rossiyskiy vestnik pe- rinatologii i pediatrii - Ros Vestn Perinatol $i$ Pediatr, 63(3), 84-90. DOI: https://doi.org/10.21508/10274065-2018-63-3-84-90 [in Russian].

8. Kucenko, T.V. (2015). Vplyv meteorologhichnykh faktoriv na pokaznyky orghanizmu ditej riznogho viku [Influence of meteorological factors on indicators of an organism of children of different age]. Visnyk Cherkasjkogho universytetu-Bulletin of Cherkasy University, 2, 67-71 [in Ukrainian].

9. Jänig, W. (2008). Integrative Action of the Autonomic Nervous System. Neurobiology of Homeostasis. Cambridge [in English].

10. Parashar, R., Amir, M., Pakhare, A. \& Rathi, P. (2016). Age Related Changes in Autonomic Functions. Journal of Clinical and Diagnostic Research, 10(3), 11-13. DOI: https://doi.org/10.7860/ JCDR/2016/16889.7497 [in English].

11. Novikov, V.S. \& Soroko, S.I. (2017). Fiziologicheskie osnovy zhiznedeyatelnosti cheloveka v ekstremalnykh usloviyakh [Physiological foundations of human life in extreme conditions]. SPb: Politekhnika-print [in Russian].

12. Khodakov, V.E., Sokolova, N.A. \& Cherny S.G. (2013). Vliyanie prirodno-klimaticheskikh faktorov na sotsialno-ekonomicheskie i proizvodstvennye sistemy: monografiya [Influence of natural and climatic factors on socio-economic and production systems: monograph]. Kherson: Grin D.S. [in Russian].

13. Gosling, S.N. et al. (2017). Adaptation to Climate Change: A Comparative Analysis of Modeling Methods for Heat-Related Mortality. Environmental Health Perspectives. DOI: https://doi.org/10.1289/ EHP634 [in English].

14. Derevyanko, Y.A. (1990). Integralnaya otsenka rabotosposobnosti pri umstvennom i fizicheskom trude. Metodicheskie rekomendatsii. [Integral assessment of mental and physical performance. Methodical recommendations]. Moskva: Ekonomika [in Russian].

15. Yabluchanskiy, M.I. et al. (2013). From physiological to pathological meteosensitivity. Journal of V.N. Karazin' KhNU, 1090, 5-8 [in English].

16. Makats, V.Gh., Kuryk, M.V., Petruk, V.Gh. \& Yermishev, O.V. (2018). Osnovy funkcionaljno-ekologhichnoji ekspertyzy (nevidoma veghetologhija) 
[Fundamentals of functional and ecological expertise (unknown vegetology)]. Vol. VI: monograph. Vinnytsia [in Ukrainian].

17. Peng, Y.-F. et al. (2016). Analyzing Personal Happiness from Global Survey and Weather Data: A Geospatial Approach. Plos one, 11(4), 1-17. DOI: https://doi.org/10.1371/journal.pone.0153638 [in English].

18. Henderson, K. \& Loreau M. (2018). How ecological feedbacks between human population and land cover influence sustainability. PLoS Comput Biol., 14(8) [in English].

19. Yermishev, O.V. \& Mudrak, O.V. (2019). Ekologhoporivnjaljnyj analiz funkcionaljnogho zdorov'ja cholovikiv riznykh vikovykh ghrup radiacijno zabrudnenykh ta umovno chystykh reghioniv Ukrajiny [Environmental and comparison analysis of functional health of men of different age groups in radiation contaminated and conditionally pure regions Ukraine]. Bioresursy i pryrodokorystuvannya - Bioresources and nature management, 11, 5-6, 112-128. DOI: http://dx.doi.org/10.31548/bio2019.05.012 [in Ukrainian].

20. Parry, M.L. et al. (2007). Climate Change: Impacts, Adaptation and Vulnerability, Contribution of Working Group II to the Fourth Assessment Report of the IPCC. Cambridge [in English].

Стаття надійшла до редакції журналу 05.09.2020 